Gut, 1979, 20, 1057-1062

\title{
Virus isolation studies in Crohn's disease: a negative report
}

\author{
R. J. PHILlPOTTS, J. HERMON-TAYLOR, AND B. N. BROOKE \\ From the Department of Surgery, St George's Hospital Medical School, London
}

SUMmARY Homogenates of gut and mesenteric lymph node tissue from patients with Crohn's disease, ulcerative colitis, and control patients were tested for cytopathic effect (CPE) production in a series of cell lines including rabbit ileal and WI38 cells. A CPE was produced in WI38 cells by tissue homogenates from patients with Crohn's disease, ulcerative colitis, and control patients. Evidence was obtained to suggest that this effect, although superficially similar to a viral CPE, was due to toxic protein constituents of inflamed tissue homogenate.

Although previous isolation studies have failed to identify a virus specifically associated with Crohn's disease, either as a primary aetiological agent, or causing a secondary infection (Schneierson et al., 1962; Kyle et al., 1963; Farmer et al., 1973), there is evidence that viruses may be present in Crohn's disease tissue. Dobbins and Siemers (1972) have found ultrastructural changes in gut tissue from Crohn's disease patients suggestive of virus infection, and Riemann (1977) was able to find virus-like particles in gut tissue from seven of nine patients with Crohn's disease.

Aronson et al. (1975) have reported the isolation of a small RNA virus from Crohn's disease and control tissues using WI38 human embryo lung cells and a modified co-cultivation technique. The virus, which had the characteristics of an enterovirus, was recovered from both lymphoid tissue and intestine.

Subsequently, the ability of Crohn's disease gut tissue homogenates to cause a cytopathic effect (CPE) in rabbit ileal and WI38 cell cultures has been demonstrated, and the virus of Aronson et al. (the 'Vermont agent') seen in thin-section electron microscopy (Gitnick and Rosen, 1976). These workers have since shown that CPE produced by homogenates of gut tissue is inhibited by low dilutions of serum from Crohn's disease patients. The CPE could also be passaged repeatedly, was produced in chick and duck embryo cell cultures, but was also found in some of the control tissues. A variety of virus-like particles in the range 40-90 $\mathrm{nm}$ were found in thin sections of cell cultures showing CPE; the size differences were interpreted as being due to the presence or absence of a protein

Received for publication 29 June 1979 coat (Gitnick and Rosen, 1977; Gitnick 1978; Rosen et al., 1978).

The isolation of a reovirus-like agent from gut tissue homogenates has also been reported from Vermont, but, unlike those isolated by Gitnick (1978) and the original Vermont agent, this virus was not isolated from any control tissues (Whorwell et al., 1977).

The object of the present study was to attempt to confirm these results, and to isolate and identify viruses from Crohn's disease tissue by sensitive and specific techniques.

\section{Methods}

PATIENTS

Gut tissue and mesenteric lymph nodes were taken at surgery from a total of 17 Crohn's disease patients, all of whom had active disease. At the time of surgery, seven were taking azathioprine, one salazopyrine, and the remaining nine were not being treated with any immunosuppressive or anti-inflammatory agents. The control series consisted of gut and mesenteric lymph node tissue from 25 patients (eight carcinoma of the colon, six acute appendicitis, two familial polyposis coli, one diverticular disease, one duodenal ulcer); tissue from six cases of ulcerative colitis was also examined. No antibiotic or physical cleansing techniques were used to prepare the bowel for surgery.

\section{TECHNIQUES}

Gut and mesenteric lymph node tissue was cut into 2-3 $\mathrm{mm}^{3}$ pieces immediately after removal, dropped directly into liquid nitrogen, and stored at $-70^{\circ} \mathrm{C}$. Saline homogenates of frozen tissue were prepared 
in the Biotec X-press (LKB Instruments, Sweden), and diluted to $10 \% \mathrm{w} / \mathrm{v}$ original tissue with 199 maintenance medium (MM) before inoculation into cell cultures, or storage in $1 \mathrm{ml}$ aliquots of $-70^{\circ} \mathrm{C}$.

In other cases, diseased tissue was washed six times in Earles balanced salt solution (EBSS) containing penicillin and streptomycin $(\mathrm{P} / \mathrm{S}) 100$ units $/ \mathrm{ml}$ and gentamicin $100 \mu \mathrm{g} / \mathrm{ml}$. A $20 \%$ tissue homogenate was prepared in $199 \mathrm{MM}$, coarse debris removed by centrifugation at $1200 \mathrm{~g}$ for 10 minutes, and the supernatant filtered sequentially through Millipore membranes of $5 \mu \mathrm{m}, 800 \mathrm{~nm}, 650 \mathrm{~nm}$, and $220 \mathrm{~nm}$ pore diameter. The final filtrate was inoculated directly into cell cultures, and the remainder stored in $1 \mathrm{ml}$ aliquots at $-70^{\circ} \mathrm{C}$.

\section{Cell cultures}

Reagents were obtained from Flow Laboratories, Irvine, Ayrshire, Scotland. Vero cells (Yasamura and Kawakita, 1963) were grown in 199 medium supplemented with $10 \%$ inactivated fetal calf serum, $\mathrm{P} / \mathrm{S} 100$ units $/ \mathrm{ml}$, and $\mathrm{NaHCO}_{3} 0.85 \mathrm{~g} / \mathrm{l}$ and maintained in the same medium, but with $2 \%$ inactivated fetal calf serum and $\mathrm{NaHCO}_{3} 1.68 \mathrm{~g} / \mathrm{l}$. Tube cultures were prepared at weekly intervals, and maintained after inoculation by medium changes at three to four day intervals.

BCL-DI cells, a diploid line of human embryo lung fibroblasts (Grand Island Biological Co. Ltd., Scotland), were used between passages 19-26. They were grown in Eagle's minimal essential medium (MEM) $+10 \%$ fetal calf serum, 20 mM HEPES buffer, $2 \mathrm{mM}$ L-glutamine, $1 \%$ non-essential amino acids supplement solution, and P/S 100 units $/ \mathrm{ml}$, and maintained in MEM $+2 \%$ inactivated fetal calf serum, $1.68 \mathrm{~g} / 1 \mathrm{NaHCO}_{3}$, with L-glutamine, HEPES buffer, and the antibiotics as before. Subcultures $(1: 2)$ were made at weekly intervals, and the maintenance medium on tube cultures was changed every three to four days. WI38 and $\mathrm{MRC}_{5}$ cells (passages 16-26) and a fibroblastic line of human fetal ileal cells (HFI, passages 4-10) were grown, subcultured, and used as described for BCL-Dl cells; in this case, however, the maintenance medium was 199.

Rabbit ileal cells were obtained from three sources: (1) fetal rabbit ileum prepared by trypsinisation and used between passages 6-20 (REG cells, kindly donated by Dr R. Bucknall); (2) derived in this laboratory by trypsinisation of ileal segments from six week old New Zealand white rabbits and used between passages 3-20 (RG cells); the growth, maintenance, and subculture of REG and RG cells was as for $\mathrm{MRC}_{5}$ and WI38 cells; (3) derived from explants of six week old New Zealand white rabbit ileum according to the method of Gitnick et al. (1976). Tube cultures were not prepared from these cells, but confluent cell sheets between passages 3-10 were changed onto MEM maintenance medium as required. No medium changes were made after inoculation.

\section{Arcton 113 extraction of tissue homogenates}

Equal volumes of tissue homogenates and arcton 113 (ICI Petrochemicals Division, UK) were mixed and centrifuged at $1200 \mathrm{~g}$ for four minutes. The aqueous phase was used for cell culture inoculation.

\section{Inoculation of cell cultures and passage}

The inoculum volume was standardised as $10 \% \mathrm{v} / \mathrm{v}$ of the cell culture fluid; unless otherwise stated, the medium was changed after 24 hours' incubation. For passage, cell cultures were frozen and thawed three times, the disrupted cells and cell culture fluid centrifuged at $1200 \mathrm{~g}$ for four minutes and the supernatant used to inoculate additional cell cultures, or stored at $-70^{\circ} \mathrm{C}$.

\section{Immunofluorescence}

Heat inactivated serum samples from patients not taking any immunosuppressive drugs, and who had not recently undergone surgery were used in an indirect test for the presence of viral antigens in inoculated cell cultures. Cytomegalovirus (CMV) infected cells and a serum known to contain antibody to CMV v'ere used to control the method.

\section{Culture of human rotavirus from Crohn's disease tissues}

The method was based on that of Bryden et al. (1976). Fresh tissue homogenate $(0 \cdot 1 \mathrm{ml})$ was added to coverslip cultures of WI38 cells in flat-bottomed plastic tubes which were centrifuged at $1000 \mathrm{~g}$ for one hour at room temperature, the tissue homogenate withdrawn, and $1 \mathrm{ml}$ of maintenance medium added. After overnight incubation at $37^{\circ} \mathrm{C}$ the medium was changed, and incubation continued for a total of 14 days. Paired coverslips for each homogenate were removed and examined by indirect immunofluorescence on the seventh and 14th days using serum from a gnotobiotic calf, which had undergone infection with calf diarrhoea virus, diluted $1: 20$.

\section{Ultra-violet irradiation}

$0.5 \mathrm{ml}$ aliquots of tissue homogenates and cell culture fluids to be irradiated were pipetted into $30 \mathrm{~mm}$ plastic petri dishes and exposed for 30 minutes without lids to a 15 watt UV ( $\lambda 254 \mathrm{~nm}$ ) lamp at a distance of $3 \mathrm{~cm}$, before inoculation into cell cultures. Each irradiation dose was controlled using a parallel series of cell culture fluids containing $10^{6.25}$ cell culture infective doses $/ \mathrm{ml}\left(\mathrm{CCD}_{50} / \mathrm{ml}\right)$ of rhinovirus No. 2. CPE production by tissue homo- 
genates and survival of the rhinovirus (at $33^{\circ} \mathrm{C}$ ) was tested using WI38 target cells. Unirradiated controls were run simultaneously in an identical manner.

\section{Acid phosphatase estimation}

Acid phosphatase was estimated as a marker of lysosomal enzyme activity using Boehringer Mannheim colourimetric test kit, No. 15988 TSAA, which follows the hydrolysis of p-nitrophenyl phosphate at $\mathrm{pH} \mathrm{4 \cdot 8}$. Results were expressed as milliunits of acid phosphatase activity $\mathrm{ml}^{-1}$ of tissue homogenate.

\section{Neutralisation tests}

Sera from four Crohn's disease patients who were neither taking immunosuppressive drugs nor had undergone surgery recently (two had active disease and two were in remission), two control patients (one carcinoma of the colon, and the other with familial polyposis coli) and fetal calf serum were used in a neutralisation test as follows. Equal volumes of heat inactivated serum diluted $1 / 5$ with $10 \%$ fresh guinea-pig serum in PBS and tissue homogenate were mixed and incubated at $37^{\circ} \mathrm{C}$ for one hour before $0.2 \mathrm{ml}$ of each mixture was inoculated into WI38 cell cultures. Homogenate diluted with an equal volume $10 \%$ fresh guinea-pig serum in PBS and serum + an equal volume of 199 maintenance medium were included as controls.

\section{Sephadex 6100 fractionation}

Two $20 \mathrm{ml}, 25 \%$ w/v homogenates (one Crohn's disease and one ulcerative colitis) were chromatographed on a column of Sephadex G100 $(5 \times 85 \mathrm{~cm})$ equilibrated with PBS. The eluate was collected in $10 \mathrm{ml}$ fractions at a flow rate of $10 \mathrm{ml} / \mathrm{h}$. The elution profile was determined by reading the optical density at $280 \mathrm{~nm}$. Peak fractions were pooled, and concentrated to about $5 \mathrm{ml}$ by dialysis against $10 \%$ polyethylene glycol (molecular weight $18-20 \times 10_{3}$ in PBS for 24 hours at $4^{\circ} \mathrm{C}$. Concentrated peaks were divided into $1 \mathrm{ml}$ aliquots and tested for CPE production in WI38 cells.

The column was later calibrated using blue dextran, bovine serum albumin (68 000) ovalbumin (43 000), trypsinogen $(24000)$, and red cytochrome (12 000) as molecular weight markers (Andrews, 1965). CPE production by these fractions after digestion for four hours at $37^{\circ} \mathrm{C}$ with a sepharose immobilised protease from Streptomyces griseus (Miles Laboratories Inc., Slough, Buckinghamshire) was also tested.

\section{Results}

HOMOGENATES PREPARED FROM FROZEN TISSUE

Homogenates from six Crohn's disease patients (four colon, two ileum), five controls, and two patients with ulcerative colitis were passaged twice for six weeks in Vero cell cultures by incubation stationary at $37^{\circ} \mathrm{C}$. No CPE was produced, and indirect immunofluorescence using sera from five Crohn's disease patients with active colonic disease, and one ulcerative colitic failed to show any specific fluorescence in cells from the first passage cultures. The same series of homogenates were given two similar six week passages in BCL-D1 cells, at $37^{\circ} \mathrm{C}$. Again, no CPE was produced, and indirect immunofluorescence with the same sera was again negative.

Homogenates from six patients with Crohn's disease (three ileum, three colon), six controls, and two ulcerative colitics) were given two four week passages in $\mathrm{MRC}_{5}$ cells, incubated stationary at $37^{\circ} \mathrm{C}$. No $\mathrm{CPE}$ was seen. The same homogenates were also passaged once in $\mathrm{MRC}_{5}$ cells incubated for six weeks, rolling at $33^{\circ} \mathrm{C}$ and without medium changes after the initial change at 24 hours after inoculation. Again, no CPE was produced, and immunofluorescence with the panel of sera described was again negative.

Thirteen Crohn's disease tissue homogenates (six colon, five ileum, two mesenteric lymph node), 12 controls, and three ulcerative colitics were given one six week passage in human fetal ileal cells, incubated stationary at $37^{\circ} \mathrm{C}$. None produced any CPE. The same series were given two four week passages in RG and REG cells, incubated stationary at $37^{\circ} \mathrm{C}$ and rolling at $33^{\circ} \mathrm{C}$. No CPE was produced in either cell line by any homogenate.

Homogenates prepared from fresh tissue: seven Crohn's disease tissue homogenates from six patients (five colon, one rectal biopsy, and one lymph node), six controls and three ulcerative colitics were inoculated into $25 \mathrm{~cm}^{2}$ cell culture flasks of explant derived rabbit ileal cells as described by Gitnick et al. (1976). On incubation without maintenance medium changes at $37^{\circ} \mathrm{C}$ in humidified $5 \% \mathrm{CO}_{\varepsilon}$ in air, all cell cultures showed signs of degeneration within five to six days, the cells rounding up, shrinking, and detaching from the growth surface, leaving islands of normal cells. By the 14th day, $70-80 \%$ of the cell sheet was degenerate. This occurred with all Crohn's disease, control, and ulcerative colitis cultures, as well as in uninoculated cultures. On the 14th day the maintenance medium was replaced with growth medium, and incubation continued. Within seven days, all cell sheets had re-grown, producing confluent monolayers of normal appearance.

None of the eight Crohn's disease tissue homogenates from seven patients (five colon, two mesenteric lymph node, one rectal biopsy), the 16 controls or the five ulcerative colitics produced any CPE in 

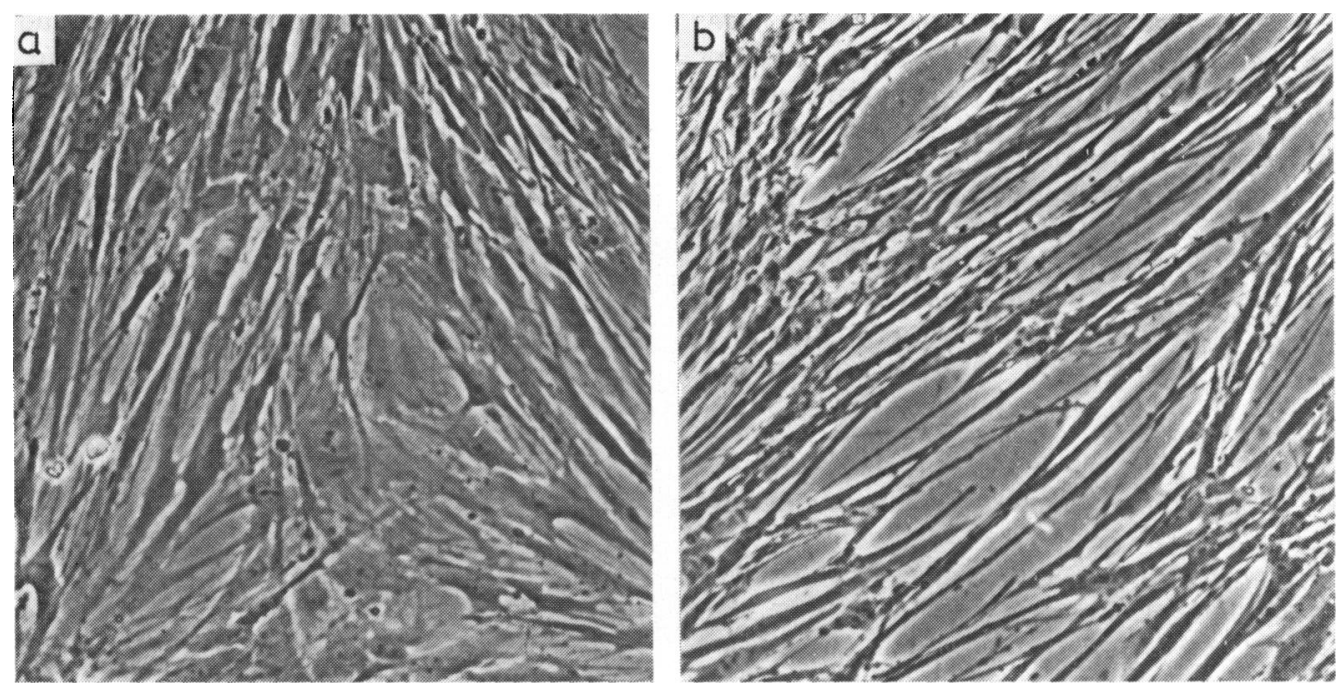

Fig. 1 WI38 cell cultures (a) four days after inoculation with homogenate of fresh colon tissue from carcinoma of the colon $(\times 375)$, and $(b)$ four days after inoculation with homogenate of fresh colon tissue from Crohn's disease $(\times 375)$.

coverslip cultures of WI38 cells. No specific fluorescence was found with the calf anti-rotavirus serum on either the seventh or 14th days.

Twelve Crohn's disease tissue homogenates from 10 patients (six colon, one ileum, four lymph node, and one rectal biopsy), the previous 16 controls and six ulcerative colitics were given three two week passages in WI38 cells. Six ulcerative colitis (five colon, one mesenteric lymph node), six Crohn's disease and six acute appendicitis specimens produced a definite CPE in WI38 cell cultures (Fig. 1). The effect was usually visible after two to four days, but sometimes took up to 10 days to appear. The severity of the CPE was increased by doubling the

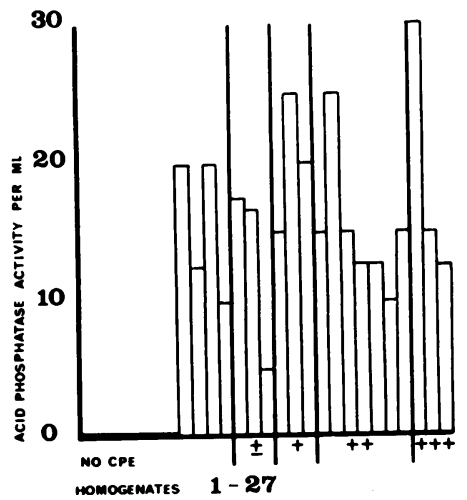

Fig. 2 Acid phosphatase activity and CPE production by fresh tissue homogenates $( \pm=$ variable $)$. inoculum size, when rounding up and shrinkage of the cells were observed, followed by detachment from the glass. Regular medium changes reduced, but did not prevent, this CPE, and the CPE from four Crohn's disease specimens and one ulcerative colitis specimen was passaged three times. One cycle of arcton 113 extraction did not prevent the CPE produced by the three ulcerative colitis and four Crohn's disease colon homogenates tested, nor did a dose of ultra-violet irradiation shown to kill $10^{6.25} \mathrm{CCD}_{50}$ of rhinovirus no. 2. CPE from one ulcerative colitis homogenate and three Crohn's disease colon homogenates was not inhibited by any of the four Crohn's disease and three control sera that were tested. However, dilution of the original $20 \%$ tissue homogenates 1:5 with 199 prevented CPE production in all cases. Acid phosphatase levels in the 27 homogenates did nol

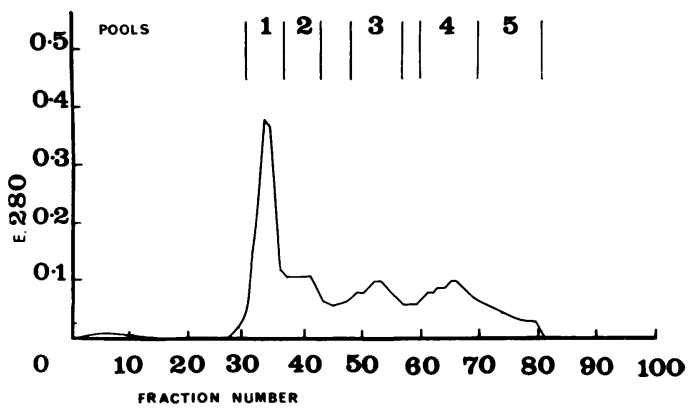

Fig. 3 Elution profile of the ulcerative colitis tissue homogenate. CPE was produced by fractions 1 and 3 . 


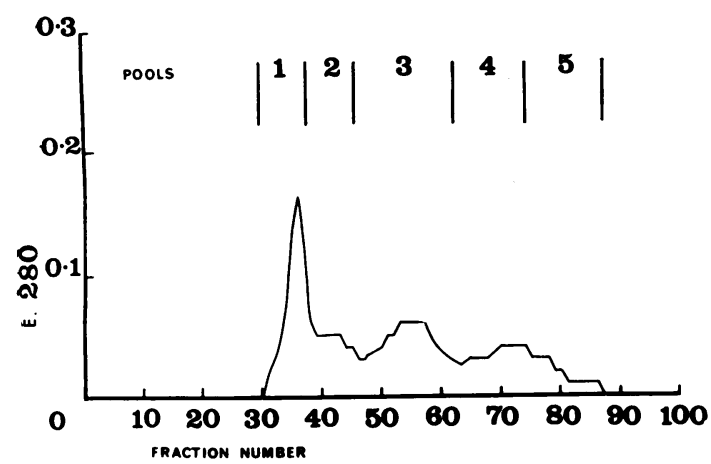

Fig. 4 Elution profile of the Crohn's disease tissue homogenate. CPE was produced by fractions 4 and 5 .

correlate with CPE production (Fig. 2).

The elution profiles of the Sephadex G100 chromatographed homogenates are shown in Figs. 2 and 4. Five pooled fractions were prepared from each as indicated, concentrated, and tested for CPE production. Cytopathic activity was found in fractions 1 (molecular weight $>100000$ ) and 3 (m.wt. 40-60 000) of the chromatographed ulcerative colitis homogenate, and in fractions 4 (m.wt. 25-35 000) and 5 (m.wt. $<25000$ ) of the chromatographed Crohn's disease colon homogenate. The cytopathic activity in these fractions was destroyed by treatment with immobilised $S$. griseus protease.

\section{Discussion}

In this study, frozen or fresh extracts of diseased intestine and regional lymph node from a total of 16 patients with active Crohn's disease were examined for the presence of a virus using eight different types of cell cultures under a variety of conditions. No cytopathic agent identifiable as a virus was detected. These negative findings are in agreement with the reports of some other workers (Schneierson et al., 1962; Kyle et al., 1963; Farmer et al., 1973).

Such results, however, do not exclude the involvement of a virus in the pathogenesis of Crohn's disease, as the culture conditions and types of cell cultures used may not have been suitable for the growth of a putative 'Crohn's disease virus'. However, they fail to confirm the results of Aronson et al. (1975), Gitnick et al. (1976), Whorwell et al. (1977), and Gitnick (1978). Long term immunosuppressive therapy may encourage persistent viral infections, and reports of virus isolations from Crohn's disease tissues may be due to the presence of such 'opportunists'. Of the Crohn's disease patients studied, seven were taking azathioprine. The failure to isolate viruses from any of these suggests that such a mechanism cannot account for the discrepancies in published results.

In the present study, a CPE was produced in the WI38 cell cultures which could be passaged, occasionally appeared to be focal, and could appear up to 10 days after inoculation. At first, when it was found to be associated with Crohn's disease and ulcerative colitis tissues it was thought that it might be due to a virus. However, its presence in extracts of acutely inflamed appendices, the direct relationship of CPE production to inoculum size, the failure of ultra-violet light and Crohn's disease serum to inhibit the CPE, and the abolition of the CPE by dilution of homogenates, all indicated that non-viral toxicity was responsible. This toxicity appeared to adsorb to the cell surface, as it was not prevented by medium changes. It was associated with fractions in a variety of molecular weight ranges, and, as it was susceptible to proteolysis, was probably protein in origin. There was no evidence to suggest that lysosomal enzymes were responsible.

That tissue homogenates may prove toxic to cell cultures is well known to virologists. This observation illustrates the difficulties of virus isolation from such materials, and emphasises the need for adequate controls.

The authors are indebted to Dr R. Bucknall of ICI, Macclesfield, England, for the human and rabbit fetal ileal cell lines, and to Anthony Magee and David Grant for their biochemical advice. This project was supported by a grant from the Medical Research Council.

\section{References}

Andrews, P. (1965). The gel-filtration behaviour of proteins related to their molecular weights over a wide range. Biochemical Journal, 96, 595-606.

Aronson, M. D., Phillips, C. A., Beeken, W. L., and Forsyth, B. R. (1975). Isolation and characterization of a viral agent from intestinal tissue of patients with Crohn's disease and other intestinal disorders. Progress in Medical Virology, 21, 165-176.

Dobbins, W. O., and Siemers, P. T. (1972). A viral etiology for inflammatory bowel disease? (Abstract) Gastroenterology, 62, 742.

Farmer, G. W., Vincent, M. M., Fuccillo, D. A., HortaBarbosa, L., Ritman, S., Sever, J. L., and Gitnik, G. L. (1973). Viral investigations in ulcerative colitis and regional enteritis. Gastroenterology, 65, 8-18.

Gitnik, G. L. (1978). The course and character of viral infection in Crohn's disease and ulcerative colitis (Abstract). Gastroenterology, 74, 1038.

Gitnick, G. L., Arthur, M. H., and Shibata, I. (1976). Cultivation of viral agents in Crohn's disease. Lancet, 2, 215-217.

Gitnick, G. L., and Rosen, V. J. (1976). Electron microscopic studies of viral agents in Crohn's disease. Lancet, 2, 217-219. 
Gitnick, G. L., and Rosen, V. J. (1977). Viral investigations in inflammatory bowel disease (Abstract). Gastroenterology, 72, 1062.

Kyle, J., Bell., T. H., Porteous, I. B., and Blair, D. W. (1963). Factors in the aetiology of regional enteritis. Bulletin de la Société Internationale de Chirugie, 22, 575-584.

Riemann, J. F. (1977). Further electron microscopic evidence of virus-like particles in Crohn's disease. Acta Hepato-Gastroenterologica, 24, 116-118.

Rosen, V. J., Gitnik, G. L., Hertweck, S. A., and Arthur, M. A. (1978). Electron microscopy of viruses in inflammatory bowel disease (Abstract). Gastroenterology, 74, 1087.

Schneierson, S. S., Garlock, J. H., Shore, B., Stuart, W. D., Steinglass, M., and Aronson, B. (1962). Studies on the viral etiology of regional enteritis and ulcerative colitis: a negative report. American Journal of Digestive Diseases, 7, 839-843.

Whorwell, P. J., Phillips, C. A., Beeken, W. L., Little, P. K., and Roessner, K. D. (1977). Isolation of Reoviruslike agents from patients with Crohn's disease. Lancet, 1, 1169-1171.

Yasamura, Y., and Kawakita, Y. (1963). Research in SV40 by tissue culture. Nippon Rimsho, 21, 1201-1219. 